\title{
APLIKASI HEALTH BELIEF MODEL DALAM MENGANALISIS PERILAKU PENGGUNAAN KACAMATA PELINDUNG
}

\author{
HEALTH BELIEF MODEL APPLICATIONS FOR ANALYZING \\ BEHAVIOR TO USE SAFETY GLASSES
}

Zernike Victoria Sakinah

Departemen Promosi Kesehatan dan Ilmu Perilaku, Fakultas Kesehatan Masyarakat, Universitas Airlangga, Surabaya.

Email: zernikevictoriasakinah@gmail.com

\begin{abstract}
The number of work accidents in Indonesia is still the highest in Southeast Asia. Accidents can be caused by several factors such as environmental, mechanical or human behavior. Work accident data at PT Lintech Duta Pratama Surabaya shows that accidents are still a lot of in this company. The dominant cause of work accidents in PT Lintech Duta Pratama Surabaya is the behavior of workers who do not use personal protective equipment is safety glasses. Therefore, this study aims to determine the factors that affect the behavior of workers and use safety glasses according to the concept of HBM in order to reduce the high number of work accidents caused by unsafe behavior. This research is a Cross Sectional study where the research is done in a certain time. The sample of this study is the total of the working population in the production section of 74 people. Data analysis this research is binary logistic regression test. The results showed that there was an influence between education $(\rho=0.015)$, knowledge $(\rho=0.047)$, self efficacy $(\rho=0.027)$, cues to action $(\rho=0.000)$ with behavior in the use of safety glasses but. No correlation between ages $(\rho=0.065)$, perceived susceptibility $(\rho=0.712)$, perceived seriousness $(\rho=0.208)$, perceived benefit ( $\rho=0.063)$, perceived barrier $(\rho=0.565)$ with behavior in the use of safety glasses. The conclusions of this study are between knowledge education, self efficacy, cues to action to be associated with behavior in the use of safety glasses.
\end{abstract}

Keywords: behavior, health belief model, work accident, PPE

Abstrak: Angka kecelakaan kerja di Indonesia masih menempati urutan tertinggi pada wilayah Asia Tenggara. Kecelakaan dapat disebabkan oleh beberapa faktor seperti lingkungan, mekanis atau perilaku manusia itu sendiri. Data kecelakaan kerja di PT Lintech Duta Pratama Surabaya menunjukkan bahwa kecelakaan kerja masih banyak terjadi pada perusahaan ini. Penyebab dominan terjadinya kecelakaan kerja di PT Lintech Duta Pratama Surabaya ialah perilaku pekerja yang tidak menggunakan alat pelindung diri (APD) yaitu kacamata pelindung. Maka dari itu penelitian ini bertujuan untuk mengetahui faktor yang memengaruhi perilaku pekerja dam menggunakan kacamata pelindung menurut konsep Health Belief Model (HBM) agar dapat mengurangi tingginya angka kecelakaan kerja yang disebabkan oleh perilaku tidak aman. Penelitian ini merupakan penelitian Cross Sectional dimana penelitian ini dilakukan dalam kurun waktu tertentu. Sampel dalam penelitian ini adalah total dari populasi pekerja pada bagian produksi sebanyak 74 orang. Analisis data dalam penelitian ini adalah uji regresi logistik biner. Hasil penelitian menunjukkan bahwa terdapat pengaruh antara pendidikan $(\rho=0,015)$, pengetahuan $(\rho=0,047)$, kemampuan diri yang dirasakan $(\rho=0,027)$, pendorong untuk bertindak $(\rho=0,000)$ dengan perilaku penggunaan kacamata pelindung sedangkan usia $(\rho=0,065)$, persepsi kerentanan yang dirasakan $(\rho=0,712)$, persepsi keseriusan yang dirasakan $(\rho=0,208)$, persepsi manfaat yang dirasakan $(\rho=0,063)$, persepsi hambatan yang dirasakan $(\rho=0,565)$ tidak ada hubungan dengan perilaku penggunaan kacamata pelindung. Kesimpulan dari penelitian ini adalah antara pendidikan pengetahuan, kemampuan diri yang dirasakan, pendorong untuk bertindak memiliki hubungan dengan perilaku penggunaan kacamata pelindung.

Kata kunci: perilaku, health belief model, kecelakaan kerja, APD 


\section{PENDAHULUAN}

Kemajuan ilmu pengetahuan dan teknologi memberikan dampak yang baik terhadap kemajuan perindustrian Indonesia. Kemajuan sektor industri Indonesia juga diimbangi oleh Sumber Daya Manusia dan produktivitas kerja yang baik. Untuk meningkatkan produktivitas kerja harus didukung oleh lingkungan kerja yang sehat dan aman (Lamm, Massey, Perry, 2006). Produktivitas kerja berkaitan erat dengan tenaga kerja karena memiliki keterkaitan dengan output yang dihasilkan. Di sisi lain, perusahaan harus memberikan perlindungan terhadap tenaga kerja karena mereka memiliki hak memperoleh perlindungan atas keselamatan dan kesehatan kerja (UndangUndang Ketenagakerjaan No 13 Tahun 2003).

Menurut International Labour Organization (ILO), secara global ada lebih dari 250 juta kecelakaan di tempat kerja setiap tahunnya dan 160 juta pekerja menjadi sakit yang disebabkan oleh bahaya di tempat kerja. Terlebih lagi, 1,2 juta pekerja meninggal akibat kecelakaan dan sakit di tempat kerja. World Health Organization (WHO) mendefinisikan kecelakaan adalah suatu kejadian yang tidak terduga yang penanggulangannya tidak dapat dipersiapkan sehingga menghasilkan cedera yang riil.

Angka kecelakaan kerja di Indonesia sudah mengalami penurunan, namun Indonesia masih menempati urutan tertinggi pada wilayah Asia Tenggara. Menurut data Badan Penyelenggara Jaminan Sosial (BPJS) Ketenagakerjaan menunjukkan bahwa angka kejadian kecelakaan kerja di Indonesia masih tinggi yaitu pada tahun 2015 tercatat 105.182 kasus kejadian kecelakaan kerja dan kasus kecelakaan berat yang mengakibatkan kematian tercatat sebanyak 2.375 kasus dari total jumlah kecelakaan kerja. Kecelakaan bukan disebabkan secara kebetulan, melainkan ada penyebabnya. Untuk mengetahui penyebab kecelakaan, kita harus melakukan penelitian agar dapat dilakukan tindakan lebih lanjut dan dapat melakukan upaya pencegahan. Kecelakaan kerja dapat disebabkan oleh beberapa faktor yaitu faktor lingkungan dan manusia (Suma'mur 2010).

Menurut Heinrich (1931) 88\% kecelakaan kerja disebabkan oleh tindakan manusia, $10 \%$ adalah kondisi mekanis atau fisik yang tidak aman, sisanya $2 \%$ ialah lainlain. Hasil penelitian Heinrich menekankan bahwa kecelakaan banyak terjadi akibat dari perilaku kesalahan manusia itu sendiri sehingga mengakibatkan suatu tindakan yang tidak aman. PT Lintech Duta Pratama Surabaya merupakan perindustrian lokal Indonesia yang bergerak pada bidang fabrication and construction service. Tingginya proses produksi yang dilakukan PT Lintech Duta Pratama setiap hari, menghadapkan pekerja pada banyaknya risiko yang ada lingkungan perusahaan. Data kecelakaan kerja di PT Lintech Duta Pratama Surabaya menunjukkan bahwa kecelakaan kerja masih banyak terjadi pada perusahaan ini.

Perilaku pekerja yang tidak patuh dalam menggunakan kacamata pelindung perlu dilakukan prediksi terhadap berbagai faktor yang mendorong perilaku pekerja dalam menggunakan kacamata pelindung. Perilaku tersebut dapat dilihat menggunakan teori Health Belief Model karena Health Belief Model dapat memprediksi kemungkinankemungkinan individu akan melakukan tindakan pencegahan tergantung pada kepercayaan individu tersebut.

Menurut Glanz, et al. (2002), Health Belief Model merupakan model kognitif yang dapat dipengaruhi oleh informasi dari lingkungan sekitar. Health Belief Model menjelaskan bahwa kemungkinan individu melakukan tindakan pencegahan tergantung pada keyakinan itu tersebut.

Health Belief Model merupakan suatu bentuk penjabaran dari sosio-psikologi. Model ini diciptakan karena adanya masalah-masalah kesehatan yang dapat dilihat dari kegagalan masyarakat atau individu dalam menerima usaha pencegahan dan penyembuhan penyakit yang diselenggarakan oleh provider kesehatan (Notoadmojo, 2007).

Sejak awal 1950, Health Belief Model (HBM) telah menjadi salah satu kerangka kerja konseptual yang paling banyak digunakan dalam penelitian perilaku kesehatan. Teori ini digunakan untuk menjelaskan perubahan dan pemeliharaan perilaku yang berhubungan dengan kesehatan dan sebagai bentuk 
orientasi intervensi perilaku kesehatan. Dalam perkembangannya HBM telah diperluas untuk mendukung intervensi dalam perubahan perilaku kesehatan. HBM digunakan untuk memprediksi mengapa orang akan mengambil tindakan untuk mencegah, untuk menyaring, atau untuk mengendalikan kondisi penyakit. HMB terdiri dari beberapa komponen yaitu: (Kerentanan yang dirasakan/Perceived Susceptibility) Merupakan persepsi kerentanan mengacu pada kepercayaan seseorang tentang kemungkinan mengalami risiko atau kemungkinan mendapatkan penyakit. (Keseriusan yang dirasakan/ Perceived Severity) Ialah keyakinan tentang dampak keparahan yang didapatkan apabila terkena penyakit atau membiarkan tidak diobati. (Persepsi Hambatan/Perceived Barrier) Keyakinan individu dalam melakukan evaluasi terhadap hambatan yang dihadapi yang mengadopsi suatu perilaku. Seseorang akan mempertimbangkan keuntungan dan konsekuensi yang didapat dalam perubahan perilaku, menimbang antara dugaan efektivitas tindakan dan persepsi bahwa tindakan tersebut mahal, bahaya (berefek samping negatif), tidak menyenangkan (sakit, sulit atau mengganggu), tidak nyaman, makan waktu dan sebagainya. (Kemampuan diri yang dirasakan/Self Efficacy) Ialah kepercayaan mengenai kemampuan yang dimiliki dalam berperilaku apakah individu tersebut bisa atau tidak dalam melakukan perubahan perilaku. Perilaku tersebut dianggap penting karena mencapai suatu hasil yang diinginkan. (Isyarat Bertindak/ Cues to Action) Cues (isyarat) yang memicu tindakan merupakan salah satu strategi untuk mendapatkan informasi dalam mendorong berperilaku baik. Contoh: media informasi, pendidikan dan gejala yang dirasakan. (Manfaat yang dirasakan/Perceived Benefit) Merupakan keyakinan individu bahwa jika dia mengubah perilakunya ke arah yang lebih baik maka, hal tersebut dapat mengurangi risiko terkena penyakit. Seseorang akan mengadopsi perilaku baru apabila perilaku tersebut dapat menghindari risiko terkena penyakit.

Berdasarkan data tersebut, terlihat ada peningkatan pada kecelakaan kerja yang terjadi dari tahun 2015 hingga 2016. Pada tahun 2015 tercatat angka kecelakaan yaitu sebanyak 2 kasus dan pada tahun 2016 terjadi peningkatan sebanyak 5 kasus.

Menurut data kecelakaan kerja PT Lintech Duta Pratama Surabaya, sebagian besar kecelakaan ialah kecelakaan pada mata seperti debu gerinda dan gram yang mengenai mata. Penyebab dominan terjadi nya kecelakaan disebabkan oleh perilaku pekerja yang tidak menggunakan alat pelindung diri yaitu kacamata pelindung. Maka dari itu artikel ini bertujuan untuk mengetahui faktor yang memengaruhi perilaku pekerja dalam menggunakan kacamata pelindung agar dapat merumuskan rencana pengendalian terhadap kecelakaan kerja yang sering terjadi.

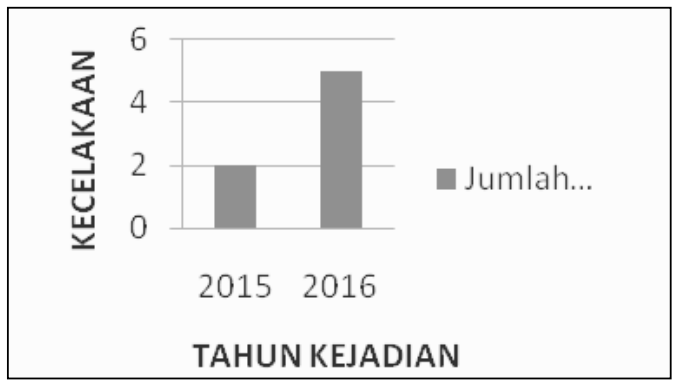

Gambar 1. Angka Kecelakaan Kerja di PT Lintech Duta Pratama Surabaya (Sumber: Data Kecelakaan Kerja PT Lintech Duta Pratama Surabaya Tahun 20152016)

\section{METODE}

Penelitian ini adalah penelitian observasional analitik karena penelitian ini bertujuan untuk menganalisis perilaku penggunaan kacamata pelindung menggunakan konsep Health Belief Model dan pendekatan yang digunakan adalah pendekatan kuantitatif. Penelitian ini merupakan penelitian Cross Sectional dimana penelitian ini dilakukan dalam kurun waktu tertentu. Populasi dalam penelitian ini adalah pekerja di area bagian produksi.

Sample dalam penelitian ini adalah total dari populasi pekerja pada bagian produksi sebanyak 74 orang. Analisis data dalam penelitian ini adalah uji regresi logistik biner. 
Variabel bebas dalam penelitian ini adalah umur, pendidikan, pengetahuan, kerentanan yang dirasakan individu, keseriusan yang dirasakan individu, hambatan yang dirasakan, manfaat yang dirasakan, kemampuan diri yang dirasakan, dan pendorong dalam berperilaku. Variabel terikat dalam penelitian ini adalah perilaku penggunaan kacamata pelindung.

Instrumen data dalam penelitian ini menggunakan pengisian kuesioner dan penelitian observasi. Kuesioner yang diberikan berisi tentang persepsi kerentanan dan keseriusan, persepsi ancaman, persepsi hambatan dan manfaat faktor demografi, sosiopsikologi. Pengisian kuesioner dilakukan setelah mendengarkan penjelasan peneliti dan menandatangani Informed Consent. Pengisian kuesioner dilakukan pada jam istirahat pekerja bertempat di tempat istirahat pekerja, sedangkan observasi dilakukan melalui pengamatan secara langsung perilaku penggunaan kacamata pelindung pada saat bekerja di workshop PT. Lintech Duta Pratama Surabaya.

Teknik pengumpulan data dalam penelitian ini akan dianalisis dengan metode yang sudah dipilih. Analisis yang pertama untuk mengetahui karakteristik pekerja dari semua variabel yang diamati agar dapat diketahui proporsi dari masingmasing variabel tersebut. Hasil dari data tersebut akan disajikan dalam bentuk tabel sehingga dapat dilihat distribusi frekuensi atau bedanya proporsi masing-masing variabel yang diteliti, dan selanjutnya untuk dianalisis. Selanjutnya untuk mengetahui pengaruh antara masing-masing variabel independen dengan variabel dependen. Analisis menggunakan uji regresi logistik biner.

\section{HASIL PENELITIAN}

PT. Lintech Duta Pratama merupakan perusahaan lokal Indonesia yang sudah berdiri sejak tahun 1998 menyediakan pelayanan di bidang teknik dan bidang sipil yang bergerak dalam bidang fabrikasi, konstruksi, desain, untuk industri minyak dan gas, pertambangan, pabrik semen dan berbagai industri lainnya. PT. Lintech Duta Pratama berlokasi di Jl. Mastrip no 70 Karang Pilang Sidoarjo memiliki 120 pekerja dimana 74 pekerja di bagian produksi dan 46 pada bagian kantor. PT Lintech Duta Pratama memiliki area kerja yaitu workshop. Workshop merupakan tempat proses produksi yang ada di perusahaan. Workshop terbagi menjadi 3 area kerja workshop 1 meliputi cutting, marking machining. Workshop 2 meliputi painting and fabrication, Workshop 3 meliputi fit up and finishing. Selain itu PT. Lintech Duta Pratama juga memiliki cabang yang berlokasi di Paciran Lamongan.

Waktu kerja PT. Lintech Duta Pratama ialah pada hari Senin - Sabtu dimana Senin - Jum'at memiliki waktu kerja selama 8 jam dalam sehari yaitu dimulai pada pukul 08.00 WIB sampai pukul 16.00 WIB, sedangkan pada Hari Sabtu hanya memiliki waktu kerja selama 5 jam dalam sehari dimulai pada pukul 07.00 WIB sampai pukul 12.00 WIB. Untuk waktu istirahat pada Hari Senin - Jum'at adalah pukul 11.30-12.30 WIB, sedangkan untuk Hari Sabtu tidak memiliki waktu istirahat. Hari Sabtu tersebut hanya diperuntukkan bagi pekerja dan pengawas di bagian produksi. Pada pekerja di bagian produksi tidak memiliki pergantian shift karena jam kerja hanya sampai sore hari.

Dalam melakukan pekerjaannya PT. Lintech Duta Pratama melakukan beberapa tahapan mulai dari awal proses produksi sampai pada bagian akhir. Adapun tahapannya adalah sebagai berikut:

Proses Loading Material dilakukan diare luar workshop. Material tersebut diangkut ke gudang menggunakan forklift yang nantinya apabila material tersebut dibutuhkan, maka akan dipindahkan ke area workshop 1 dan akan diproses lebih lanjut. APD yang wajib digunakan di area ini antara lain: helm pengaman, sepatu pelindung, dan masker.

Proses Cutting Marking akan diawali dengan mendesain bentuk pola atau membuat garis pada material yang dibutuhkan kemudian akan dilakukan cutting terhadap material tersebut. Proses cutting sendiri dibagi menjadi 3 bagian yaitu: cutting torch yang digunakan untuk material seperti baja dengan mengikuti pola garis yang sudah digambar, APD yang wajib digunakan di area ini antara lain: 
helm pengaman, sepatu pelindung, masker, kacamata pelindung, alat pelindung telinga dan sarung tangan.

Selanjutnya material yang sudah dipotong akan dipanaskan menggunakan blader, hal tersebut bertujuan untuk memudahkan dalam mengebor material. Ada 2 macam mesin bor yang digunakan yaitu mesin bor kecil dan mesin bor besar. Perbedaan antara mesin bor kecil dan mesin bor besar adalah mata bor pada mesin bor besar bisa digerakkan oleh operator sedangkan mesin bor kecil tidak bisa. APD yang wajib digunakan di area ini adalah, helm pengaman, sepatu pelindung, masker, kacamata pelindung, alat pelindung telinga dan sarung tangan.

Selanjutnya material akan dimasukkan ke mesin roll untuk membentuk tabung dengan diameter yang diinginkan. APD yang wajib digunakan di area ini antara lain: helm pengaman, sepatu pelindung, masker, kacamata pelindung, alat pelindung telinga dan sarung tangan.

Tujuan dari pengelasan ini untuk membuat material menjadi satu. APD yang wajib digunakan di area ini antara lain: helm pengaman, sepatu pelindung, masker, kacamata pelindung, alat pelindung telinga dan sarung tangan.

Setelah material selesai dilas, kemudian akan dilakukan peng-gerindaan untuk memperhalus produk yang dihasilkan. Dalam menghaluskan material tersebut, pekerja menggunakan 2 jenis gerinda yaitu gerinda biasa yang digunakan untuk menghaluskan pada bagian luar sedangkan gerinda baby digunakan untuk menghaluskan material yang memiliki sudut sempit. APD yang wajib digunakan di area ini antara lain: helm pengaman, sepatu pelindung, masker, kacamata pelindung, alat pelindung telinga dan sarung tangan.

Proses sandblasting ini dilakukan untuk membersihkan material dari karat dan debu. Setelah proses sandblasting selesai maka selanjutnya bisa dilakukan proses painting. APD yang wajib digunakan di area ini adalah, helm pengaman, sepatu pelindung, masker, kacamata pelindung, alat pelindung telinga dan sarung tangan.
Proses pewarnaan bertujuan untuk membuat produk menarik dan lebih tahan terhadap karat. Setelah dilakukan pewarnaan, kemudian dilakukan quality control yang untuk memeriksa kualitas yang dihasilkan apakah sudah memenuhi syarat atau belum. APD yang wajib digunakan di area ini adalah, helm pengaman, sepatu pelindung, masker, kacamata pelindung, alat pelindung telinga dan sarung tangan.

Apabila produk sudah lolos terhadap pengecekan quality control, maka selanjutnya dilakukan pembungkusan terhadap produk tersebut yang nantinya akan didistribusikan terhadap pembeli. APD yang wajib digunakan di area ini antara lain: helm pengaman, sepatu pelindung, masker.

Berdasarkan Tabel 1 dapat diperoleh informasi bahwa perilaku penggunaan kacamata pelindung diPT. Lintech Duta Pratama sebagian besar tidak memakai kacamata pelindung yaitu persentasenya sebesar $59,5 \%$ dan untuk yang memakai kacamata pelindung persentasenya sebesar $40,5 \%$.

Tabel 1. Distribusi Responden Berdasarkan Perilaku Penggunaan Kacamata Pelindung di PT. Lintech Duta Pratama Tahun 2017

\begin{tabular}{lcc}
\hline $\begin{array}{l}\text { Perilaku Penggunaan } \\
\text { Kacamata Pelindung }\end{array}$ & F & $\mathbf{( \% )}$ \\
\hline Memakai & 30 & 40,5 \\
Tidak memakai & 44 & 59,5 \\
\hline Total & $\mathbf{7 4}$ & $\mathbf{1 0 0 , 0}$ \\
\hline
\end{tabular}

Berdasarkan Tabel 2 dapat diperoleh informasi bahwa sebagian besar responden berumur 26-30 tahun yaitu sebanyak 36,5\%, sedangkan yang paling sedikit ialah pada umur 41-45 tahun yaitu 5,4\%.

Setiap individu memiliki karakteristik yang berbeda dimana nantinya karakteristik tersebut dapat memengaruhi persepsi individu dan secara tak langsung dapat memengaruhi perilaku kesehatan. Karakteristik individu dalam penelitian ini terdiri dari usia, pendidikan dan pengetahuan. Menurut Bandura (1994) karakteristik individu dapat memiliki efek 
Tabel 2. Karakteristik Berdasarkan Umur Responden di PT. Lintech Duta Pratama Tahun 2017

\begin{tabular}{lrr}
\hline Umur (tahun) & F & $(\mathbf{\%})$ \\
\hline $20-25$ & 11 & 14,9 \\
$26-30$ & 27 & 36,5 \\
$31-35$ & 6 & 8,1 \\
$36-40$ & 15 & 20,3 \\
\hline Total & $\mathbf{7 4}$ & $\mathbf{1 0 0}$ \\
\hline
\end{tabular}

yang tidak langsung pada perilaku yang dapat memengaruhi persepsi individu tentang kerentanan, keseriusan, manfaat, hambatan dan self efficacy.

Hasil penelitian menunjukkan bahwa jumlah karyawan yang memiliki umur muda lebih banyak dibandingkan dengan jumlah karyawan yang berumur tua. Distribusi usia menunjukkan bahwa responden berumur 26-30 tahun yaitu sebanyak $36,5 \%$, sedangkan yang paling sedikit ialah pada umur 41-45 tahun yaitu 5,4\%. Menurut hasil uji statistik menunjukkan bahwa tidak ada pengaruh antara usia terhadap perilaku penggunaan kacamata pelindung. Hasil penelitian ini sejalan dengan penelitian Halimah (2010) yang menyatakan tidak perbedaan yang bermakna antara usia dengan perilaku aman. Rusmerie (2016) menyatakan bahwa usia tidak berpengaruh terhadap perilaku perawat dalam melaporkan kejadian kecelakaan kerja. Oleh sebab itu semua pekerja tanpa memandang usia harus mematuhi peraturan perusahaan selama berada di tempat tugas yang sama.

Berdasarkan Tabel 3 dapat diperoleh informasi bahwa sebagian besar tingkat pendidikan responden SMA yaitu sebanyak $79,7 \%$, sedangkan yang paling sedikit ialah tidak pernah bersekolah yaitu $4,1 \%$.

Menurut Notoatmodjo (2012), pendidikan merupakan salah satu faktor yang dapat memengaruhi perilaku. Pendidikan juga akan memengaruhi individu dalam mencegah penyakit serta menjaga dan meningkatkan kemampuan dalam memelihara kesehatannya.

Pada distribusi tingkat pendidikan menunjukkan bahwa sebagian besar tingkat pendidikan responden SMA yaitu sebanyak 79,7\%. Hasil uji statistik menunjukkan bahwa ada pengaruh antara pendidikan
Tabel 3. Distribusi Frekuensi Tingkat Pendidikan Responden di PT. Lintech Duta Pratama Tahun 2017

\begin{tabular}{lrr}
\hline Tingkat Pendidikan & F & (\%) \\
\hline Tidak Sekolah & 3 & 4,1 \\
SD & 0 & 0,0 \\
SMP & 7 & 9,5 \\
SMA & 59 & 79,7 \\
Sajana & 5 & 6,8 \\
\hline Total & $\mathbf{7 4}$ & $\mathbf{1 0 0 , 0}$ \\
\hline
\end{tabular}

terhadap perilaku penggunaan kacamata pelindung. Hal ini sejalan dengan yang dinyatakan oleh Bandura bahwa tingkat pendidikan seseorang akan berpengaruh terhadap persepsi seseorang sehingga orang tersebut dapat membentuk perilaku sehat. Oleh sebab itu, pendidikan pekerja yang didominasi oleh SMA seharusnya memiliki pengetahuan dan pola pikir yang lebih tinggi dibandingkan dengan pekerja yang menempuh pendidikan SD atau SMP sehingga dapat tercipta perilaku sehat di tempat kerja.

Berdasarkan Tabel 4 dapat diperoleh informasi bahwa pengetahuan tentang kacamata pelindung di PT. Lintech Duta Pratama dalam kategori pengetahuan baik yaitu sebanyak $86,5 \%$ dan untuk kategori pengetahuan kurang baik hanya 2,7\%.

Green (1980) menyatakan bahwa dalam melakukan peningkatan pengetahuan tidak selalu dapat melakukan perubahan perilaku, namun pengetahuan sangat perlu diberikan sebelum individu melakukan suatu tindakan. Tindakan akan sesuai dengan pengetahuan apabila individu menerima isyarat yang cukup kuat untuk memotivasi dalam bertindak sesuai dengan pengetahuannya.

Tabel 4. Distribusi Responden Berdasarkan Pengetahuan di PT. Lintech Duta Pratama Tahun 2017

\begin{tabular}{lrc}
\hline Pengetahuan & F & (\%) \\
\hline Kurang Baik & 2 & 2,7 \\
Cukup Baik & 8 & 10,8 \\
Baik & 64 & 86,5 \\
\hline Total & $\mathbf{7 4}$ & $\mathbf{1 0 0 , 0}$ \\
\hline
\end{tabular}


Berdasarkan hasil penelitian diperoleh informasi bahwa ada pengaruh antara pengetahuan terhadap perilaku penggunaan kacamata pelindung. Pengetahuan sendiri dapat dipengaruhi oleh faktor pendidikan dimana semakin tinggi tingkat pendidikan, semakin tinggi pula pengetahuan seseorang. Akan tetapi seseorang yang berpendidikan rendah belum tentu berpengetahuan rendah karena pengetahuan tidak hanya bisa didapat pada pendidikan formal saja, akan tetapi dapat diperoleh dari pendidikan non formal.

Hasil tersebut sesuai dengan pendapat James (2003) yang menyatakan informasi akan memberikan pengaruh terhadap pengetahuan. Semakin banyak informasi yang didapat semakin meningkat pula pengetahuan seseorang sehingga hal itu dapat memengaruhi perilaku seseorang dalam melakukan pencegahan. Notoatmodjo (2007) menyatakan bahwa semakin tinggi pengetahuan seseorang, maka semakin besar pula kemungkinan seseorang berperilaku sesuai dengan pengetahuan yang didapatkannya.

Berdasarkan Tabel 5 dapat diperoleh informasi bahwa kerentanan yang dirasakan responden dalam kategori merasa rentan persentasenya sebesar $75,7 \%$ dan untuk kategori kurang rentan persentasenya 2,7\%

Persepsi kerentanan merupakan persepsi subjektif seseorang terhadap risiko yang akan terjadi dari kondisi kesehatan yang dialaminya. Kerentanan yang dirasakan merupakan salah satu persepsi yang dapat mendorong seseorang untuk mengadopsi perilaku sehat. Sangat memungkinkan apabila seseorang merasa dirinya memiliki risiko, maka orang tersebut akan melakukan tindakan pencegahan, namun terkadang

Tabel 5. Distribusi Responden Berdasarkan Persepsi Kerentanan yang dirasakan di PT. Lintech Duta Pratama Tahun 2017

\begin{tabular}{lrc}
\hline Kerentanan & F & $\mathbf{( \% )}$ \\
\hline Kurang Rentan & 2 & 2,7 \\
Cukup Rentan & 16 & 21,6 \\
Merasa Rentan & 56 & 75,7 \\
\hline Total & $\mathbf{7 4}$ & $\mathbf{1 0 0 , 0}$ \\
\hline
\end{tabular}

seseorang merasa dirinya tidak berisiko atau memiliki risiko yang kecil sehingga orang tersebut cenderung akan melakukan perilaku tidak sehat.

Persepsi kerentanan yang dirasakan pekerja apabila tidak menggunakan kacamata pelindung saat melakukan pekerjaan merasa akan mendapatkan kecelakaan kerja seperti terkena percikan gram, kemasukan debu, terkena radiasi dan lain-lain. Berdasarkan pertimbangan ini akan muncul kerentanan yang dirasakan bahwa dirinya akan mengalami kecelakaan kerja yang memiliki dampak kerugian yang akan diterima oleh dirinya.

Hasil penelitian ini menunjukkan bahwa tidak ada pengaruh antara kerentanan yang dirasakan terhadap perilaku penggunaan kacamata pelindung. Hasil penelitian ini sejalan dengan penelitian Bosch Anderson et al., (2010) menyatakan bahwa kerentanan yang dirasakan tidak memiliki pengaruh terhadap perilaku penggunaan alat pelindung diri untuk menghindari risiko terkena zoonosis. Penelitian Rusmerie (2016) bahwa kerentanan yang dirasakan tidak mampu memengaruhi perilaku melaporkan kejadian kecelakaan kerja Penelitian ini juga sejalan dengan yang dinyatakan oleh Notoatmodjo (2012), meskipun kesadaran seseorang tentang kesehatan sudah tinggi, namun praktik terhadap perilaku sehat seseorang masih rendah. Pada penelitian ini dapat dilihat bahwa meskipun responden sudah memiliki persepsi kerentanan yang baik, belum tentu responden tersebut melakukan perilaku menggunakan kacamata pelindung sebagai tindakan pencegahan.

Berdasarkan Tabel 6 dapat diperoleh informasi bahwa keseriusan yang dirasakan responden di PT. Lintech Duta Pratama

Tabel 6. Distribusi Responden Berdasarkan Persepsi Keseriusan yang dirasakan di PT. Lintech Duta Pratama Tahun 2017

\begin{tabular}{lrc}
\hline Keseriusan & F & $\mathbf{( \% )}$ \\
\hline Kurang Serius & 1 & 1,4 \\
Cukup Serius & 46 & 62,2 \\
Merasa Serius & 27 & 36,5 \\
\hline Total & $\mathbf{7 4}$ & $\mathbf{1 0 0 , 0}$ \\
\hline
\end{tabular}


dalam kategori cukup serius persentasenya sebesar $62,2 \%$ dan untuk kategori kurang serius persentasenya $1,4 \%$.

Persepsi individu tentang keseriusan dan parahnya suatu penyakit yang akan diderita apabila tidak menggunakan kacamata pelindung akan mendorong seseorang untuk melakukan perilaku pencegahan. Semakin serius suatu penyakit yang akan diderita semakin besar pula tindakan seseorang dalam melakukan pencegahan.

Persepsi keseriusan yang dirasakan pekerja terhadap dampak kecelakaan kerja yaitu khawatir dirinya akan mengalami sakit, cacat bahkan kematian. Dampak ini akan membuat pekerja mencari cara untuk melakukan tindakan pencegahan agar tidak terjadi kerugian terhadap dirinya.

Menurut Mc Cornik Brown (1999), keseriusan yang dirasakan berpengaruh terhadap keyakinan individu tentang keseriusan atau keparahan penyakit yang ditimbulkan. Sedangkan persepsi keseriusan sering didasarkan oleh informasi medis atau pengetahuan yang juga berasal dari kepercayaan seseorang tentang dampak dari penyakit tersebut.

Penerimaan seseorang tentang persepsi keseriusan yang dirasakan didasarkan oleh pengetahuan, pengalaman penyakit dan gangguan kesehatan yang pernah dialaminya. Selain itu faktor eksternal seperti pesan di media, nasihat dan lainlain dapat memengaruhi seseorang dalam penerimaan persepsi keseriusan yang dirasakan.

Berdasarkan penelitian ini menunjukkan bahwa tidak ada pengaruh antara persepsi keseriusan yang dirasakan terhadap perilaku penggunaan kacamata pelindung. Hal ini sejalan dengan penelitian Bosch Anderson et al., (2010) menyatakan bahwa persepsi

Tabel 7. Distribusi Responden Berdasarkan Persepsi Manfaat yang Dirasakan di PT. Lintech Duta Pratama Tahun 2017

\begin{tabular}{lrc}
\hline Manfaat & F & $\mathbf{( \% )}$ \\
\hline Kurang Bermanfaat & 0 & 0,0 \\
Cukup Bermanfaat & 40 & 54,1 \\
Merasa bermanfaat & 34 & 45,9 \\
\hline Total & $\mathbf{7 4}$ & $\mathbf{1 0 0 , 0}$ \\
\hline
\end{tabular}

keseriusan yang dirasakan tidak memiliki pengaruh terhadap perilaku penggunaan alat pelindung diri untuk menghindari risiko terkena zoonosis.

Berdasarkan Tabel 7 dapat diperoleh informasi bahwa manfaat yang dirasakan responden di PT. Lintech Duta Pratama dalam kategori cukup bermanfaat. Apabila kita lihat persentasenya sebesar $54,1 \%$ untuk kategori cukup bermanfaat sedangkan untuk kategori kurang bermanfaat persentasenya sebesar $0 \%$.

Persepsi manfaat yang dirasakan yaitu keyakinan seseorang merasa dirinya rentan, maka orang tersebut akan melakukan tindakan tertentu dan tindakan yang dilakukan tersebut tergantung pada manfaat yang akan dirasakannya nanti. Persepsi positif ini akan menentukan seseorang dalam melakukan pengambilan keputusan untuk berperilaku sehat.

Manfaat dari perilaku menggunakan kacamata pelindung ialah mendapat perlindungan di tempat kerja, menghindari terulangnya kembali kecelakaan kerja, meminimalisir kerugian yang akan diperoleh dan dapat meningkatkan keselamatan dari perilaku tersebut.

Berdasarkan hasil penelitian dapat diperoleh informasi bahwa tidak ada pengaruh antara persepsi manfaat yang dirasakan terhadap perilaku penggunaan kacamata pelindung. Rata-rata responden memiliki persepsi manfaat cukup, namun dalam implementasinya responden cenderung tidak melakukan perilaku baik. Hal ini dapat diperkuat oleh penelitian Larkin et al., (2007) yang menyatakan bahwa persepsi manfaat yang dirasakan tidak memiliki pengaruh terhadap perilaku penggunaan alat pelindung diri pada petani sebagai pencegahan terkena pestisida. Penelitian ini sejalan dengan yang dikatakan Hochbaum (1958) apabila penerimaan seseorang tentang kerentanan dan keseriusan yang dirasakan dapat membentuk perilaku seseorang tetapi hal tersebut belum tentu cukup dalam menentukan tindakan yang akan diambil ke depannya. Meskipun persepsi manfaat yang dirasakan cukup, namun belum tentu hal tersebut dapat membuat sesorang melakukan perilaku pencegahan. Sama halnya dengan penelitian 
ini, meskipun responden memiliki persepsi kacamata pelindung memiliki cukup manfaat namun hal tersebut tidak mampu memengaruhi perilaku dalam menggunakan kacamata pelindung.

Berdasarkan Tabel 8 dapat diperoleh informasi bahwa hambatan yang dirasakan responden di PT. Lintech Duta Pratama dalam sebagian besar pada kategori hambatan kurang yaitu persentasenya sebesar $56,8 \%$ dan untuk kategori banyak hambatan persentasenya $4,1 \%$.

Hambatan yang ditemukan dalam melakukan tindakan pencegahan memiliki pengaruh terhadap usaha yang dilakukan seseorang. Semakin tinggi hambatan yang dirasakan, semakin kecil usaha yang dilakukan namun apabila hambatan yang dihadapi kecil maka akan semakin besar kemungkinan melakukan tindakan pencegahan.

Hambatan pekerja dalam menggunakan kacamata pelindung ialah lupa memakai kacamata pelindung karena sudah terbiasa tidak menggunakannya, merasa tidak nyaman menggunakan kacamata pelindung karena mereka merasa kacamata pelindung justru menghalangi penglihatan mereka.

Berdasarkan hasil penelitian didapatkan bahwa tidak ada pengaruh antara persepsi hambatan yang dirasakan terhadap perilaku penggunaan kacamata pelindung. Hal ini menunjukkan bahwa seseorang yang memiliki persepsi hambatannya kurang, tidak memiliki pengaruh terhadap perilaku pencegahan.

Penelitian ini sejalan dengan yang dikatakan Larkin et al., (2007) tentang bahwa persepsi hambatan yang dirasakan tidak memiliki pengaruh terhadap perilaku petani dalam menggunakan alat pelindung diri sebagai upaya pencegahan terkena pestisida.

Hochbaum (1958) bahwa keseimbangan antara manfaat dan hambatan yang dirasakan kemungkinan dapat memengaruhi perubahan perilaku seseorang seperti yang diinginkan, tetapi tidak selalu menunjukkan mereka akan selalu bertindak. Pengaruh Kemampuan Diri Yang Dirasakan Terhadap Perilaku Penggunaan Kacamata Pelindung

Berdasarkan Tabel 9 dapat diperoleh informasi bahwa pada variabel kemampuan diri yang dirasakan responden di PT. Lintech Duta Pratama dalam sebagian besar dalam kategori merasa yakin persentasenya sebesar $58,1 \%$ dan untuk kategori kurang yakin persentasenya $0 \%$.

Perilaku seseorang untuk melakukan tindakan pencegahan dapat dipengaruhi oleh seberapa yakin kemampuan individu tersebut dalam melakukan perilaku sehat sehingga dari perilaku tersebut akan menghasilkan perubahan perilaku yang diinginkan.

Kemampuan diri yang dirasakan (selfefficacy) adalah prediktor kuat dari perilaku promosi kesehatan (Robinson, 2012). Rasa percaya diri terhadap kemampuan diri (self efficacy) dapat menimbulkan peningkatan motivasi diri dalam melakukan perubahan gaya hidup pada pasien (Maes dan Karoly, 2005).

Berdasarkan hasil penelitian menunjukkan bahwa ada pengaruh antara kemampuan diri yang dirasakan terhadap perilaku penggunaan kacamata pelindung. Oleh sebab itu perilaku penggunaan kacamata pelindung dapat dipengaruhi oleh seberapa yakin individu tersebut dalam menggunakan kacamata pelindung sehingga timbul perilaku pencegahan.

Hal ini sejalan dengan penelitian Eftathiou Georgios et al., (2011)

Tabel 8. Distribusi Responden Berdasarkan Persepsi Kerentanan yang Dirasakan di PT. Lintech Duta Pratama Tahun 2017

\begin{tabular}{lrr}
\hline Hambatan & F & $\mathbf{( \% )}$ \\
\hline Banyak & 3 & 4,1 \\
Cukup & 29 & 39,2 \\
Kurang & 42 & 56,8 \\
\hline Total & $\mathbf{7 4}$ & $\mathbf{1 0 0 , 0}$ \\
\hline
\end{tabular}

Tabel 9. Distribusi Responden Berdasarkan Kemampuan Diri yang Dirasakan di PT. Lintech Duta Pratama Tahun 2017

\begin{tabular}{lrc}
\hline Kemampuan Diri & F & $\mathbf{( \% )}$ \\
\hline Kurang Yakin & 0 & 0,0 \\
Cukup Yakin & 31 & 41,9 \\
Merasa Yakin & 43 & 58,1 \\
\hline Total & $\mathbf{7 4}$ & $\mathbf{1 0 0 , 0}$ \\
\hline
\end{tabular}


menyatakan bahwa kemampuan diri yang dirasakan memiliki pengaruh terhadap kepatuhan perawat dalam menggunakan alat pelindung diri untuk menghindari paparan terhadap mikroorganisme. Kemampuan diri yang dirasakan merupakan komponen penting dalam perubahan perilaku kesehatan (Onoruoiza, 2015). Kemampuan diri yang dimiliki oleh seseorang dapat digunakan untuk memprediksi perilaku sehat dan dapat memfasilitasi modifikasi perilaku seseorang. Orang lebih cenderung mengadopsi perilaku kesehatan jika mereka berpikir mereka akan berhasil. Pengaruh Pendorong Untuk Bertindak Terhadap Perilaku Penggunaan Kacamata Pelindung.

Berdasarkan Tabel 10 dapat diperoleh informasi bahwa pendorong untuk bertindak bagi responden di PT. Lintech Duta Pratama dalam kategori pendorong baik persentasenya sebesar $56,8 \%$ dan untuk kategori pendorong kurang persentasenya $0 \%$.

Pendorong untuk bertindak merupakan rangsangan yang dapat meningkatkan motivasi seseorang dalam melakukan perubahan perilaku. Rangsangan tersebut bisa berasal dari internal maupun eksternal.

Berdasarkan hasil penelitian menunjukkan bahwa ada pengaruh antara pendorong untuk bertindak terhadap perilaku penggunaan kacamata pelindung. Dari data tersebut dapat dilihat bahwa pendorong untuk bertindak memiliki hubungan yang kuat untuk memotivasi individu dalam menggunakan kacamata pelindung. Hal ini sejalan dengan penelitian. Eftathiou Georgios, etc et al (2011) menyatakan bahwa ada pengaruh isyarat untuk bertindak terhadap kepatuhan perawat dalam menggunakan alat pelindung diri untuk menghindari paparan terhadap mikroorganisme. Apabila seseorang

Tabel 10. Distribusi Responden Berdasarkan Pendorong Untuk Bertindak di PT. Lintech Duta Pratama Tahun 2017

\begin{tabular}{lrc}
\hline Pendorong & F & $(\%)$ \\
\hline Kurang & 0 & 0,0 \\
Cukup & 32 & 43,6 \\
Baik & 42 & 56,8 \\
\hline Total & $\mathbf{7 4}$ & $\mathbf{1 0 0 , 0}$ \\
\hline
\end{tabular}

memiliki pendorong untuk bertindak yang baik maka besar kemungkinan akan melakukan tindakan pencegahan. Sebaliknya apabila seseorang memiliki pendorong untuk bertindak yang kurang maka besar kemungkinan tidak akan melakukan tindakan pencegahan.

\section{KESIMPULAN}

Pendidikan, pengetahuan, kemampuan diri yang dirasakan, dan pendorong untuk bertindak merupakan faktor yang berpengaruh terhadap perilaku penggunaan kacamata pelindung, sedangkan usia, persepsi kerentanan yang dirasakan, persepsi keseriusan yang dirasakan, persepsi manfaat yang dirasakan, persepsi hambatan yang dirasakan tidak memiliki pengaruh terhadap perilaku penggunaan kacamata pelindung.

\section{DAFTAR PUSTAKA}

Alfiyah Rohma Nur. 2015. Gambaran Kelelahan Kerja Pada Pekerja Area Workshop 2 PT. Lintech Duta Pratama Surabaya. Skripsi. Universitas Airlangga.

Badan Penyelenggara Jaminan Sosial (BPJS) Ketenagakerjaan. 2016. Jumlah kecelakaan di Indonesia Masih Tinggi. Tersedia di: http://www.bpjsketenagakerjaan.go.id/ berita/5769/Jumlah-kecelakaan-kerjadi-Indonesiamasih-tinggi.html. [22 November 2016].

Bandura, A. 1994. Self-efficacy. In R.J. Corsini(Ed.), Encyclopedia of Psychology (2nd ed., Vol.3, pp. 368-369). New York: Wiley.

Bosch Anderson, Stacey, Leong, Kirsten, Musgrave, Karl, Powers, Jenny and Wong, David. 2010. Zoonotic Disease Risk Perception and Use of Personal Protective Measures among Wildlife Biologists an Application of the Health Belief Model. Tersedia di: https://www. researchgate. net/publication/233449077Zoonotic Disease_Risk_Perception_and_Use_of_Personal_Protective_Measures_among Wildlife_Biologists_An_Application_ of_the_Health_Belief_Model.

Departemen Kesehatan RI, Pusat Promosi Kesehatan, Panduan Pelatihan 
Komunikasi Perubahan Perilaku untuk KIBBLA, Jakarta 2008.

Eftathiou, Georgios, et al. 2011. Factors influencing nurses' compliance with Standard Precautions in order to avoid occupational exposure to microorganisms Tersedia di: https://bmcnurs.biomedcentra 1.com/articles/10.1186/1472-6955-10-1 [12 Juli 2017].

Frank Bird, Jr. and George L, Germany. 1996 "Practical Loss Control Leaders hip", Loganville, Georgia.

Glanz, K., Rimer, B.K., Lewis. 2002. Health Behavior and Health Education: Theory, research, and Practice. $3^{\text {rd }}$ Edition. San Fancisco: Jossey Bass publisher.

Green, Lawrence. 1990. Health Education Planning A Diagnostic Approach. Baltimore. The John Hopkins University, Mayfield Publishing Co.

Halimah, Siti. 2010. Faktor yang Memengaruhi Perilaku Aman Karyawan di PT. Sim Plant Tambun II Tahun 2010. Skripsi. Universitas Diponegoro. Tersedia di: http://repository.uinjkt.ac.id/dspace/ bit stream/123456789/627/1/92636SITI\%20 HALIM AH-FKIK.pdf.

Heinric H.W. 1931. Industrial Accident; a scientific approach. New York and London, McGraw-Hill Book Company, inc.

Hochbaum, G.M. 1958. Public Participation in Medical Screening Programs: A Socio-psychological Study (Public Health Service Publication No. 572). Washington, DC: Government Printing Office.

International Labour Organization. 2014. Safety and Health at Work: A Vision for Sustainable Prevention. Tersedia di: http://www.ilo.org [22 November 2016].

James J. Stapleton. 2003. Executive's guide to knowledge management: the last competitive advantage. New Jersey: John Wiley \& Sons, Inc.

Keputusan Menteri Ketenagakerjaan Nomor 150/MEN/1999 Tahun 1999 tentang Penyelenggaraan Program Jaminan Sosial Tenaga Kerja bagi Tenaga Kerja Harian Lepas, Borongan dan Perjanjian Kerja
Waktu Tertentu, Jakarta: Departemen Tenaga Kerja.

Kurniawan Budi. 2008. Risk Assessment dan Usulan Perbaikan Pada Kegiatan Pemasangan Pipa Pemboran di PT. Saripari Pertiwi Abadi Lokasi Tambang PT. Newmont Nusa Tenggara. Skripsi. Universitas Indonesia. Tersedia di: http:// lontar.ui.ac.id/file?file=digit al/1234 94S-5340-Risk\%20assesment Literatur.pdf [27 Desember 2016].

Lamm Felicity, Claire Massey \& Martin Perry. 2006. Is There a Link Between Workplace Health \& Safety, Firm Performance \& Productivity. New Zealand Journal of Employment Relations, Vol 32 No 1 (75-90).

Larkin L. Strong, Beti Thompson, Thomas D. Koepsell, Hendrika Meischke. 2007. Factors Associated With Pesticide Safety Practices in Farmworkers. Tersedia di: https://deepblue.lib.umich.edu/bitstream/ handle/2027.42/57517/20519_ftp. pdf?sequence=1. [12 Juli 2017].

Maes S, Karoly P. (2005). Self-Regulation Assessment and Intervention in Physical health and illness: A review. Applied Psychology: An International Review, 54 (2).

Mc Cornik Brown K. 1999. Health Belief Model Retrieved. Tersedia di: http:// hsc.usf.edu/ kmbrown/Health_Belief Model_Overview.htm. [07 Mei 2017].

Notoatmodjo, S. 2012. Pendidikan dan Perilaku Kesehatan. Jakarta: Rineka Cipta.

Notoatmodjo, S. 2010. Metodologi Penelitian Kesehatan. Jakarta: Rineka Cipta.

Notoatmodjo, S. 2007. Promosi Kesehatan dan Ilmu Perilaku. Jakarta: Rineka Cipta.

Notoatmodjo, S. 2005. Metodologi Penelitian Kesehatan. Jakarta: Rineka Cipta.

Notoatmodjo, S. 2003. Pendidikan dan Perilaku Kesehatan. Jakarta: Rineka Cipta.

Peraturan Menteri Tenaga Kerja dan Transmigrasi Nomor Per 01/MEN/1981 tentang Kewajiban melaporkan penyakit akibat kerja.

PT. Lintech Duta Pratama Surabaya, (2016). Data Kecelakaan Kerja. Surabaya: PT. Lintech Duta Pratama. 
Onoruoiza S.I., Musa, Umar B.D., Kunle. 2015. Using Health Beliefs Model as an Intervention to Non Compliance with Hypertension Information among Hypertensive Patient. IOSR Journal Of Humanities and Social Science (IOSRJHSS), 20(9): V.

Peraturan Menteri Tenaga Kerja Nomor 08/ MEN/VII/2010 Tahun 2010 tentang Alat Pelindung Diri, Jakarta: Departemen Tenaga Kerja.

Reese, C.D. 2009. Industrial Safety and Health for Administrative Services. CRC. Press. United States of America.

Robinson, T. 2012. Hypertension Beliefs and Behaviors of African Americans in Selected Cleveland Public Housing. Kent State University College. Disertasi.

Rusmerie, Lis Andriana R. 2016. Aplikasi Health Belief Model Untuk Menganalisis Pelaporan Kejadian Kecelakaan Kerja (Studi Kasus di rumah Sakit Suaka
Insan Banjarmasin). Thesis. Universitas Airlangga.

Suma'mur. 2009. Higiene Perusahaan dan Kesehatan Kerja (Hiperkes). Jakarta: CV. Sagung Seto.

Sheddy Tjandra. 2008. Kesekretarisan. Jilid 1. Jakarta: Direktorat Pembinaan Sekolah Menengah Kejuruan.

Undang-Undang No. 01 Tahun 1970 tentang Keselamatan Kerja. Sekretariat Negara. Jakarta.

Undang-Undang No. 13 Tahun 2003 tentang Ketenagakerjaan. Sekretariat Negara. Jakarta.

World Health Organization. 1984, Health Promotion, Tersedia di http://www.who. int/healthpromotion/about/HPR\%20 Glossary\%201998.pdf [16 Mei 2017]

World Health Organization. 1986. The Ottawa Charter for Health Promotion. Tersedia di http://www.who.int/healthpro motion/conferences/previous/ottawa/en/. [16 Mei 2017. 